\title{
Analisis penggunaan pantun sebagai komunikasi politik untuk meningkatkan popularitas kandidat
}

\author{
Rizki Arlidya $^{1 *}$, Mulia Jaya ${ }^{2}$, Ronal Dison ${ }^{3}$ \\ ${ }^{123}$ Fakultas Ilmu Sosial dan Ilmu Politik, Universitas Muara Bungo \\ *Korespondensi Penulis
}

\section{Informasi Artikel Abstrak}

Kata Kunci :

Golkar

Pantun

Politik

Kampanye

Popularitas

Histori Artikel :
Dalam melakukan kampanye suatu organisasi politik perlu emndapat dukungan banyak dari para simpatisannya. Kampanye yang dilakukan pun sebaiknya menarik dan tidak membosankan. Para kandidat biasanya menggunakan pantun dalam kampanyenya. Penelitian ini bertujuan untuk menganalisis bagaimana penggunaan pantun sebagai media komunikasi politik dalam meningkatkan popularitas kandidat. Penelitian ini merupakan penelitian deskriptif kualitatif. Penelitian ini mengambil studi kasus partai Golkar di Kabupaten Bungo. Hasil penelitian menunjukkan bahwa penggunaan pantuan sebagai komunikasi potik dalam meningkatkan popularitas kandidat digunakan dalam kampanye langsung, diskusi kelompok, dan kampanye tidak langsung. Sedangkan hambatan dalam penggunaan pantuan sebagai komunikasi potik dalam meningkatkan popularitas adalah kurangnya piawainya kandidat dalam berpantun, kurangnya pemahaman kandiat dalam meningkatkan popularitas, dan kurangnya kemampuan kandidat dalam berpidato.

Copyright (C) 2019 Jurnal Politik dan Pemerintahan Daerah 


\section{Pendahuluan}

Kehidupan manusia di dalam masyarakat, memiliki peranan penting dalam sistem politik suatu negara. Manusia dalam kedudukannya sebagai mahluk sosial, senantiasa akan berinteraksi dengan manusia lain dalam upaya mewujudkan kebutuhan hidupnya. Kebutuhan hidup manusia tidak cukup yang bersifat dasar, seperti makan, minum, biologis, pakaian dan papan (rumah). Lebih dari itu, juga mencakup kebutuhan akan pengakuan eksistensi diri dan penghargaan dari orang lain dalam bentuk pujian, pemberian upah kerja, status sebagai anggota masyarakat, anggota suatu partai politik tertentu dan sebagainya. Kehidupan politik yang merupakan bagian dari keseharian dalam interaksi antar warga negara dengan pemerintah, dan institusi-institusi di luar pemerintah (non-formal) telah menghasilkan perilaku politik dalam semua sistem politik. Oleh karena itu, seringkali kita bisa melihat dan mengukur pengatahuan-pengetahuan, perasaan dan sikap warga negara terhadap negaranya, pemerintahannya, pemimpin politik dan lain-lain.

Memasuki tahun politik dalam rangka pemilihan umum legislatif tahun 2019 mendatang, banyak bermunculan kandidat-kandidat yang mencari popularias dengan berbagai cara seperti menyelenggarakan kegiatan sosial, memasang spanduk, baleho dan media lainnya agar ia dikenali oleh masyarakat. Popularitas adalah tingkat keterkenalan di mata publik, semakin terkenal maka ia semakain populer. Salah satu cara yang dilakukan oleh kandidat agat popoler ditengah masyarakat adalah melalui pantun. Banyak kandidat yang menggunakan pantun sebagai media komunikasi didalam politik dalam meraih popularitasnya. Pantun merupakan sastra lisan yang mengandung pesan-pesan moral dan sosial, pantun terdiri dari sampiran dan isi. Sampiran adalah dua baris pertama, kerap kali berkaitan dengan alam (mencirikan budaya agraris masyarakat pendukungnya), dan biasanya tak punya hubungan dengan bagian kedua yang menyampaikan maksud dan tujuan.

Kepiawaian seorang kandidat menyampaikan orasi dan berpantun dapat meningkatkan popularitasnya dimata masyarakat. Oleh karena itu pantun sebagai suatu bentuk komunikasi harus dikemas sedemikian rupa hingga lirik-lirik yang disampaikan mudah diingatkan masyarakat.

Memasuki pemilihan anggota DPRD Kabupaten, DPRD Provinsi dan DPR RI, Dewan Pimpinan Daerah Partai Golkar Kabupaten Bungo sebagai salah satu peserta dalam pemilu, harus mempersiapkan kader-kadernya yang potensial untuk bertarung memperebutkan kursi kekuasaan. Oleh karena itu untuk memperebut dan mempertahankan kekuasaaan harus mampu meningkatkan popularitasnya agar semakin dikenali oleh masyarakat kandidiat yang diusungkan. Salah satu tata bahasa atau ajakan kepada masyaralat untuk meningkatkan popularitas kandidat adalah dengan seni berpantun. Dalam jagad politik pantun banyak digunakan pada saat orasi atau pidato. Pantun mulai dianggap sebagai komunikasi politik yang afektif, cair, mudah diterima semua lapisan masyarakat. Berdasarkan uraian tersebut di atas, peneliti tertarik untuk melakukan penelitian yang dituangkan dalam bentuk skripsi dengan judul: Analisis Penggunaan Pantun Sebagai Komunikasi Politik Untuk Meningkatkan Popularitas Kandidat (Studi Kasus pada Partai Golkar Kabupaten Bungo).

\section{Metode}

Jenis data dalam penelitian ini digolongkan menjadi dua yaitu data primer dan data sekunder. Data primer diperoleh dari observasi dan wawancara. Saat observasi, instrumen yang digunakan adalah dapat berupa lembar pengamatan, panduan pengamatan maupun alat perekam. Metode observasi dapat menghasilkan data yang lebih rinci mengenai prilaku (subjek), benda, atau kejadian (objek) dari pada metode wawancara. Dalam penelitian ini, peneliti akan melakukan wawancara kepada orang-orang yang menjadi informan. Informan dalam penelitian ini disebut dengan informan kunci (key informan). Biasanya orang yang ditunjuk sebagai informan kunci ini adalah pimpinan pada sebuah lembaga, pimpinan masyarakat atau orang yang dipandang lebih tahu tentang situasi dan kondisi penelitian. 
Adapun teknik atau cara yang digunakan untuk menemukan informan kunci dalam penelitian ini dengan menggunakan teknik Purposive sampling adalah teknik pengambilan sampel sumber data dengan pertimbangan tertentu. Maka, yang menjadi informan dalam penelitian ini berjumlah 12 orang.

Data sekunder yaitu data yang diperoleh secara tidak langsung dari objek penelitian. Pengumpulan data sekunder dalam penelitian ini adalah dengan cara studi kepustakaan, pencatatan dokumen, yaitu dengan mengumpulkan data dan mengambil informasi dari buku-buku referensi, dokumen, foto, majalah, jurnal, artikel dan internet yang dianggap relevan dengan masalah yang diteliti.

Analisis data yang dipergunakan dalam penelitian ini adalah model interaktif yang mengacu pendapat Miles dan Huberman, yang mengemukakan bahwa dalam analisis data kualitatif ada empat tahapan yang harus dilakukan secara interaktif dan berlangsung secara terus menerus sampai tuntas, yaitu:

Tahap Pengumpulan Data

Pengumpulan data berisi tentang serangkaian proses pengumpulan data yang sudah dimulai ketika awal penelitian, yakni sebelum penelitian, pada saat penelitian sampai akhir penelitian. Dalam penelitian kualitatif sebaiknya peneliti sudah berfikir dan melakukan analisis ketika penelitian baru dimulai. Proses pengumpulan data pada penelitian kualitatif tidak memiliki waktu tersendiri, melainkan sepanjang penelitian yang dilakukan, proses pengumpulan data dapat dilakukan.

Tahap Reduksi Data

Reduksi data berarti merangkum, memilih hal-hal yang pokok, memfokuskan pada hal -hal yang penting, dicari tema dan polanya dan membuang yang tidak perlu. Data yang telah dikumpulkan melalui observasi, wawancara dan dokumentasi dirangkum dan dipilih sesuai dengan fokus dari permasalahan yang diteliti dalam penelitian ini, menjadi satu bentuk tulisan (script) yang akan dianalisis sesuai formatnya masing-masing. Data-data yang tidak penting atau tidak ada hubungannya dengan fokus penelitian dibuang, data yang telah dipilih kemudian disajikan dalam penyajian data.

Tahap Penyajian Data

Penyajian (display) data merupakan hasil reduksi data yang disajikan dalam laporan secara sistematik yang mudah dibaca atau dipahami sebagai keseluruhan maupun bagian-bagian dalam konteks sebagai satu kesatuan. Penyajian data adalah analis data secara sistematis dan terperinci yang disajikan dalam pembahasan dari permasalahan-permasalahan yang diteliti dalam penelitian ini. Dengan penyajian data agar tergambar jelas jawaban-jawaban dari permasalahan-permasalahan yang pada awalnya menjadi latar belakang dan tujuan diadadakannya penelitian ini.

Tahap Penarikan Kesimpulan

Tahapan terakhir adalah penarikan kesimpulan, dimana peneliti harus memaknai datadata yang telah terkumpul dibuat dalam bentuk pernyataan singkat dan mudah dipahami dengan mengacu pada masalah yang diteliti. Dengan penarikan kesimpulan, akan tergambar dengan singkat dan jelas jawaban dari permasalahan yang dibahas dalam penelitian ini.

\section{Hasil dan Pembahasan}

Penggunaan pantun dalam orasi politik mampu meningkatkan konsenterasi para pendengar, maka setelah pantun diucapkan oleh kandidat maka akan disambut dengan tepuk tangan yang meriah dari para pendengar. Hal ini dikarenakan bait-bait pada pantun yang diucapkan oleh kandidat sangat sesuai dengan fakta-fakta dalam dunia politik. Hal ini sesuai hasil wawancara dengan Bidang Kaderisasi DPD Partai Golkar Kabupaten Bungo berikut: 
Vol 1, No 1, Juni 2019, pp. 52-60

\begin{abstract}
"Penggunaan pantun sebagai komuniasi politik yang serung disampaikana dalam orasi politik, dapat membuat si penyampai atau kandidat menjadi terkenal atau populer ditengah masyarakat, karena itu setiap bait-bait dalam pantun harus disusun sedemikian rupa sesuai dengan maksud dan tujuan dari kandidat itu sendiri. Penggunaan pantun juga dapat, meningkatkan konsenterasi audien dalam menyerap pesan-pesan yang disampaikan melalui bait-bait dalam pantun."
\end{abstract}

Berikut penggunaan pantun sebagai komunikasi politik:

\title{
1. Pantun Disampaikan dalam Kampanye Massa Langsung
}

Salah satu wujud eksistensi pantun ditengah masyarakat, banyak tokoh-tokoh politik yang memakai pantun dalam pembukaan dan penutup pidatonya, pantun juga dapat menyegarkan suasana ditengah-tengah pidato. Kemudian berdasarkan keterangan yang peneliti dapatkan bahwa pantun juga sering dipakai pada saat kampanye pemilihan kepala daerah. Terutama kampanye pada lapangan terbuka yang dihadiri oleh banyak massa. Biasanya pantun yang diucapkan dalam orasi kampanye adalah pantun yang mengingatkan massa agar memilih calon kepala daerah yang sedang melaksanakan kampanya.

Berdasarkan keterangan yang peneliti dapatkan bahwa dalam orasi atau pidato politik, pantun dapat menjadi perangsang masyarakat untuk mengingat kandidat yang menyempaikan pesan melalui pantun tersebut, sehingga kandidat menjadi terkenal atau populer, selain itu komunikasi melalui pantun juga dapat meningngkatkan partisipasi masyarakat dalam kehidupan politik. Sebagaimana dijelaskan pada kerangka teori bahwa faktor yang dapat mempengaruhi partisipasi politik adalah karena adanya rangsangan. Rangsangan tersebut mampu meningkatkan keinginan masyarakat untuk mengikuti diskusi-diskusi politik dan menentukan pilihannya. Pada umumnya pantun dalam pidato merupakan seni dalam berpidato agar pesan pidato yang disampaikan dapat didengar dengan baik oleh audien atau massa.

\section{Pantun Sebagai Komunikasi Politik Disampaikan dalam Diskusi Kelompok}

Sebagai mana telah diuraikan bahwa salah satu fungsi dari komunikasi politik adalah bahwa ia memiliki peranan yang sangat penting dalam kepekaan hingga menangkap dengan jelas keberadaan sesuatu yang ditimbulkan dalam dunia politik. Dalam diskusi kelompok atau pertemuan-pertemuan dengan kelompok masyarakat seorang kandidat, maka kandidat tersebut harus mampu menyampaikan pesan-pesan politik melalui pantun.

Bait-bait pantun tersebut menjadi komunikasi politik dan mengandung pesan politik. Sebagaimana telah diuraikan bahwa partai politik merupakan suatu kelompok terorganisir yang anggota-anggotanya mempunyai orientasi, nilai-nilai, dan cita-cita yang sama. Tujuan kelompok ini ialah memperoleh kekuasaan politik dan merebut kedudukan politik, biasanya dengan cara konstitusional untuk melaksanakan programnya, oleh karena itu salah satu upaya untuk memperoleh kekuasaan politik ialah harus mampu meningkatkan popularitas sang kandidat yang diusungkan oleh partai politik. Dukungan politik bisa didapatkan melalui komunikasi politik yang jelas, artinya mempunyai visi dan misi yang dapat menjadi rangsangan bagi masyarakat untuk memilih. Penggunaan bait-bait pantun dalam diskusi kelompok juga disampaikan oleh Sumaryono, anggota DPRD Periode 2014-2019 Fraksi Golkar dari daerah pemilihan II. 
Vol 1, No 1, Juni 2019, pp. 52-60

Dengan adanya pantun dalam komunikasi politik, maka diharapkan dapat menarik perhatian atau partisipasi masyarakat untuk ikut dalam kegiatan politik dan ikut mempengaruhi pengambilan kebijakan politik. Ruang bagi partisipasi politik adalah sistem politik. Sistem politik memiliki pengaruh untuk menuai perbedaan dalam pola partisipasi politik warga negaranya. Oleh karena itu dalam diskusi politik setiap peserta diskusi diharapkan dapat berperan aktif dengan ikut serta menyumbangkan saran atau gagasannya agar dapat menjadi bahan pertimbangan bagi semua peserta yang ada. Gagasan atau pendapat yang disampaikan dalam kegiatan diskusi ini hendaknya bersifat objektif dan menjunjung tinggi nilai kebenaran. Dengan demikian, diskusi dapat berjalan dengan lancar dan baik. Maka kandidat yang diusungkan semakin populer ditengah masyarakat.

\section{Pantun Digunakan dalam Komunikasi Politik Kampanye Massa Tidak Langsung}

Teknik komunikasi politik selanjutnya adalah teknik komunikasi kampanye massa tidak langsung yaitu pidato atau orasi yang disampaikan melalui media Radio, Televisi, dan Iklan. Dalam kesempatan ini, pantun dapat digunakan sebagai pemberi pesan kepada masyrakat untuk menentukan pilihannya. Semakin sering kandidat muncul ditengah masyarakat, baik melalui media, melalui periklanan, melalui kegiatan-kegiatan sosial maka ia akan semakin populer ditengah masyarakat. Untuk meningkatkan kepopuleran itu melalui berbagai media maka pantun sebagai komunikasi dalam politik hendaklah disampaikan sebagai pesan untuk meminta dukungan masyarakat.

Pesan dari kampanye adalah penonjolan ide bahwa sang kandidat atau calon ingin berbagi dengan pemilih. Pesan sering terdiri dari beberapa poin berbicara tentang isu-isu kebijakan. Poin-Poin ini akan dirangkum dari ide utama dari kampanye dan sering diulang untuk menciptakan kesan abadi kepada pemilih. Dalam banyak pemilihan, para kandidat partai politik akan selalu mencoba untuk membuat para kandidat atau calon lain menjadi "tanpa pesan" berkaitan dengan kebijakannya atau berusaha untuk pengalihan pada pembicaraan yang tidak berkaitan dengan poin kebijakan atau program. Sebagian besar strategis kampanye menjatuhkan kandidat atau calon lain yang lebih memilih untuk menyimpan pesan secara luas dalam rangka untuk menarik pemilih yang paling potensial. Sebuah pesan yang terlalu sempit akan dapat mengasingkan para kandidat atau calon dengan para pemilihnya atau dengan memperlambat dengan penjelasan rinci programnya.

Pesan dari pantun tersebut, bahwa kandidat mencegah masyarakat memilih kandidat lain, dan memohon agar memilih dirinya. Pada pantun tersebut maksud dan tujuan yang disampaikan sangatlah sopan dan tidak menjatuhkan kandidat lain. Pantun-pantun tersebut dapat digunakan oleh kandidat dalam melakukan komunikasi politik pada acara kampanye tidak langsung, seperti pada siaran radio dan siaran televisi, sehingga ia akan semakin populer ditengah masyarakat. Berdasarkan hasil wawancara dengan Bidang Pemenangan Pemilu DPD Partai Golkar Kabupaten Bungo mengatakan bahwa:

"Kandidat kepala daerah maupun kandiat legislatif harus mempunyai nilai jual yang harus dikomunikasikan atau disampaikan kepada masyarakat, agar masyarakat mau memilihnya. Nilai jual tersebut juga dapat disampaikan dengan menggunakan pantun pada saat melakukan kampanye, baik kampanye langsung maupun tidak langung. Pantun itu mengandung makna yang tersirat, berisi pesan-pesan, pantun juga akan lama bisa dikenang oleh masyarakat dalam menyampaikan pesan." 
Pesan kampanye dalam pantun akan cepat diserap olah audien atau masyarakat yang mendengar, dari pada pesan-pesan yang disampaikan secra langsung. Misalnya pantun yang bisa disampaikan oleh kandidat saat kampanye adalah:

“Bungo tanjung, bunga kasturi

Keduanya harum semerbak mewangi

Masyarakat mari pilih kami

Janji kami akan terbukti"

Dari pantun tersebut kandidat menyampaikan bahwa apabila ia terpilih maka janjijanjinya kepada masyarakat akan dibuktikan. Oleh karena itu, pantun tersebut mampu meningkatkan popularitasnya sehingga mampu menarik keikutsertaan masyarakat untuk mendukung kandidat yang bersangkutan.

5.1 Hambatan dalam Menggunakan Pantun dalam Komunikasi Politik untuk Meningkatkan Popularitas Kandidat

Pantun dalam orasi politik digunakan hanya sebagai seni dalam berpidato atau seni dalam menyampaikan pesan. Berdasarkan hasil penelitian ditemukan bahwa penggunaan pantun dalam komuniasi politik masih belum optimal. Karena banyak kandidat kepala daerah maupun kendidat legislatif yang tidak menggunakan pantun dalam menyampaikan pesan-pesan politiknya. Berikut adalah hambatan dalam menggunakan pantun dalam komunikasi politik, sehingga todak dapat meningkatkat popularitas kandidat:

\section{Kurang Piawainya Kandidat dalam Berpantun}

Sebagaimana telah diuraikan bahwa pantun dapat meningkatkan popularitas seorang kandidat, karena bait-bait yang disampaikan dalam pantun mengandung pesan untuk memilih dan mendukungnya. Namun karena kurang piawainya seorang kandidat dalam berorasi dan menggunakan pantun sebagai media untuk berkomunikasi dengan masyarakat menjadi salah satu hambatan dalam meningkatkan popularitas kandidat. Meskipun banyak cara untuk meningkatkan popularitas namun penggunaan pantun ini merupakan cara yang mudah dan praktis dalam membuat seorang kandidat dikenal oleh masyarakat.

Kurang piawainya kader partai politik dalam menggunakan pantun dalam pidato politik diakui oleh salah satu kader DPD Partai Golkar Kabupaten Bungo atau kandidat DPRD Kabupaten Bungo periode 2019-2014 berikut:

"Saya senang mendengar pantun, namun ketika saya berpidato saya kurang pandai dalam merangkai bait demi bait sehingga menjadi ucapan yang indah dan lama untuk diingatkan oleh masyarakat."

Berdasarkan hasil wawancara di atas, maka dapat dikatakan bahwa penggunaan pantun dalam pidato politik untuk meningkatkan popularitas terkendala karena kurang piawainya kandidat dalam merangkai bait-bait dalam pantun. Penggunaan pantun Pantun bisa muncul secara spontanitas pada diri kandidat saat sedang berpidato, dan bisa juga melalui konsep yang telah disiapkan.

Oleh karena itu, maka wajar saja masih banyak kandidat terutama kandidat legislatif yang kurang piawai dalam mengucapkan pantun pada saat pertemuan-pertemuan dengan masyarakat, sehingga popularitasnya kurang dikenali oleh masyarakat, meskipun ia mempunyai elektabilitas yang tinggi dalam kepemimpinannya dan loyalitas terhadap partainya. Sehingga ia menjadi kurang populer ditengah masyarakat karena kurangnya kemampuan kandidat dalam memperkenalkan diri baik citra, karir dalam politik dan profilnya. 


\section{Kurangnya Pengetahuan Kandiat dalam Meningkatkan Popularitas}

Sebelum seorang kandiat melakukan kerja-kerja politik untuk mendongkrak tingkat elektabilitas (keterpilihan), pertama-tama yang harus dilakukan adalah meningkatkan popularitas (keterkenalan). Tahap menaikkan elektabilitas sudah masuk pada tahap tawaran politik kepada masyarakat pemilih. Sebelum memasukai tahapan eletabilitas, seorang kandidat harus dikenal baik oleh calon pemilih. Karena bisa jadi, tawaran politik seorang kandidat lebih baik, tetapi oleh karena kandidat yang bersangutan tidak dikenal atau tidak populer, maka masyarakat enggan memilih. Karena popularitas adalah indikator untuk mengukur seberapa jauh kandidat dikenal oleh pemilih. Kurangnya pemahaman kandidat, khsusnya kandidat legislatif dalam meningkatkan popularitas juga diakui Ketua DPD Partai Golkar berikut:

"Faktor yang menyebabkan gagalnya kandidat untuk dipilih oleh masyarakat adalah

karena mereka kurang atau cara meningkatkan popularitasnya, poplaritas itu dapat ditingkatkan memalui citra, karir politik dam profil kandidat."

Penggunaan pantun juga dapat meningkatkan popularitas kandidat, apalagi jika kandidat mempunyai kemampuan bernyanyi dan berpantun, maka kandidat tersebut akan semakin populer ditengah masyarakat, namun karena banyaknya kandidat yang kurang mengetahi cara meningkatkan popularutasnya maka ia bisa gagal dalam pertarungan memperebutkan kursi DPRD Kabupaten Bungo.

Oleh karena itu,Untuk meningkatkan popularitas dan citra cara yang bisa ditempuh oleh kandidat adalah melalui komunikasi media baik elektronik, cetak, sampai umbul-umbul dan spanduk termasuk berpantun, karena pantun mampu meningkatkan popularitas kandidat.

Seorang kandidat harus mengidentifikasi dan memetakan kekuatan dan kelemahan dia dan juga pesaingnya dari berbagai sisi popularitas, citra, karir politik dan profilnya sebelum melakukan program kampanye dan komunikasi kepada pemilih, sehingga program kampanyenya lebih efektif dan efisien serta tepat sasaran.

\section{Kurangnya Kemapuan Kandidat dalam Berpidato}

Tidak semua kader partai politik khususnya yang mau bertarung dalam memperebutkan kursi DPRD Kabupaten Bungo yang mampu menguasai tata cara berorasi atau tata cara berpidato, sehingga tidak mampu mempengaruhi masyarakat untuk mengenal dirinya dan menjadi pendukungnya maupun memilihnya. Kemampun berpidato dari seorang kandidiat legislatif mempunyai nilai tambah terhadap penilaian masyarakat layak atau tidak layaknya kandidat tersebut untuk dipilih.

Apabila kandidat tidak mampu menguasai tekhnik berkomunikasi melalui pidato atau orasi, maka masyarakat akan kurang bersemangat melihatnya dan mendengar apa yang disampaikannya, oleh karena itu untuk meningkatkan partisipasi masyarakat, maka kemampuan berpidato atau berorasi harus dikuasi oleh kandidat terutama dalam menyusun kalimat-kalimat. Dengan batasan waktu yang sangat singkat, kandidat harus mampu menyampaikan semua yang akan menjadi tujuan dan visi misinya. Apabila susunan kalimat pidato tidak tersrtuktur maka isi pidato akan sulit untuk dipahami oleh masyarakat. maka untuk melengkapi pesan yang disampaikan melalui pantun haruslah pantun yang selalu dapat diingat oleh masyarakat.

Pantun dalam komunikasi politik yang disampaikan pada saat pidato atau orasi, dapat menarik perhatian audien sesaat, namun secara umum tidak mampu meningkatkan partisipasi masyarakat untuk memilih calon kandidat yang bersangkutan. Hal ini sesuai dengan hasil wawancara dengan Ketua Harian DPD Partai Golkar Kabupaten Bungo berikut:

"Pantun itu seni dalam berpidato, pantun dapat mencairkan suasana saat audien mulai jenuh mendengar orasi politik atau pidato politik, pantun memang mengandung pesanpesan didalam bait-baitnya, sehingga pabtun mampu membuat seorang kandidat menjadi populer." 
Vol 1, No 1, Juni 2019, pp. 52-60

Sebagaimana telah diuraikan bahwa salah satu bentuk untuk meningkatkan popularitas kandidat itu dalah dengan cara menyampaikan profil, citra, riwayat karir kandidat melalui pidato politik, namun karena kurangnya kemampuan dalam berpidato maka popularitas soerang kandidat menjadi menurun.

Jadi dapat disimpulkan bahwa pantun sebagai komunikasi politik dapat berpengaruh signitifikan dalam meningkatkan popularitas kandiat, namun namun karena kurangnya kemampuan dalam berpidato, maka pantun menjadi hal yang sulit untuk disampaikan, sehingga tidak ada seni dalam berpidato yang berakibat kurangnya popularitas kandidat.

\section{Kesimpulan}

Berdasarkan penelitian yang telah dilakukan pada Dewan Pimpinan Daerah Partai Golkar Kabupaten Bungo, dengan mengumpulkan data melalui observasi dan wawancara. Kemudian melakukan analisis terhadap data tersebut, maka dapat ditarik beberapa kesimpulan yang berkaitan dengan topik dalam pembahasan skripsi ini, kemudian dapat pula peneliti uraikan beberapa saran terkait adanya hambatan dalam menggunakan pantun sebagai komunikasi politik unyuk meningkatkan popularitas kandidat. Adapun kesimpulan dari penelitian ini adalah penggunaan pantuan sebagai komunikasi potik dalam meningkatkan popularitas kandidat digunakan dalam kampanye langsung, diskusi kelompok, dan kampanye tidak langsung. Sedangkan hambatan dalam penggunaan pantuan sebagai komunikasi potik dalam meningkatkan popularitas adalah kurangnya piawainya kandidat dalam berpantun, kurangnya pemahaman kandiat dalam meningkatkan popularitas, dan kurangnya kemampuan kandidat dalam berpidato.

Disarankan agar kandidat dapat menggunakan pantun sebagai salah satu cara meningkatkan popularitasnya, pimpinan partai politik agar meberikan pendidikan dan pelatihan kepada kader agar mampu meningkatkan popularitas, kandidat dapat meningkatkan kemampuan dalam berpidato, partai politik dapat meningkatkan partisipasi masyarakat untuk menggunakan hak suaranya dalam memilih salah satu kandidat. 


\section{Daftar Pustaka}

\section{$\underline{\text { Buku-Buku }}$}

[1] Agus Trianto, Seni dan Budaya Nusantara, Erlangga, Jakarta, 2007.

[2] Djama'an Satori dan Aan Komariah, Metodologi Penelitian Kualitatif, Alfabeta, Bandung, 2013.

[3] Freddy Rangkuti. Analisis Swot Teknik Membedah Kasus Bisnis, Gramedia Pustaka, Jakarta, 2006.

[4] Hafied Cangara, Komunikasi Politik Konsep Teori, dan Strategi, Jakarta, Rajawali Press, Grafindo Persada, 2009.

[5] George R. Terry, Ilmu Manajemen, Bumi Aksara, Jakarta, 2009.

[6] Hadari Nawawi, Metode Penelitian Bidang Sosial, Gadjah Mada Univercity Press, Yogyakarta, 2001.

[7] Meriam Budiardjo, Dasar-Dasar Ilmu Politik, Edisi Revisi, Jakarta, Gramedia Pustaka Utama. 2013.

[8] Mochtar Pabottinggi, "Komunikasi Politik dan Transformasi Ilmu Politik" dalam Indonesia dan Komunikasi Politik, Jakarta, Gramedia, 2003.

[9] Mukhtar, Metode Praktis Penelitian Deskriptif Kualitatif, GP Press Group. Jakarta, 2001

[10] Ramlan Surbakti, Memahami Ilmu Politik, Jakarta, Gramedia Widiasarana Indonesia, 2010.

[11] Samuel P. Huntington dan Joan Nelson, Partisipasi Politik di Negara Berkembang,, Jakarta, Rineka Cipta, 2000.

[12] Suharsimi Arikunto, Prosedur Penelitian Suatu Pendekatan Praktik, , Rineka Cipta, Jakarta, 2003.

[13] Venus Antar. Manajemen Kampanye; Panduan Teoritis Dan Praktis Dalam Mengefektifkan Kampanye Komunikasi, Simbiosa Rekatam Media, Bandung, 2004.

\section{Kamus}

[1] W.J.S. Poerwadarminta, Kamus Umum Bahasa Indonesia, Balai Pustaka, Jakarta, 2003.

\section{Peraturan Perundang-Undangan}

[1] Undang-Undang Dasar Republik Indonesia Tahun 1945.

[2] Undang-undang Nomor 2 Tahun 2008 tentang Partai Politik.

[3] Undang-Undang Nomor 1 Tahun 2015 tentang Pemilihan Umum Anggota Dewan Perwakilan Rakyat, Dewan Perwakilan Daerah, Dan Dewan Perwakilan Rakyat Daerah.

\section{Website}

https://id.wiktionary.org/wiki/popularitas

https://www.google.com/search?q=indikator+popularitas + kandidat\&ie=utf-8\&oe=utf- $8 \&$ client=firefoxb-ab. 